\title{
Advances in the Characterization of the Pyrenophora tritici-repentis-Wheat Interaction
}

\author{
Lynda M. Ciuffetti and Robert P. Tuori
}

Department of Botany and Plant Pathology, Oregon State University, Corvallis 97331.

Accepted for publication 9 March 1999.

\begin{abstract}
Ciuffetti, L. M., and Tuori, R. P. 1999. Advances in the characterization of the Pyrenophora tritici-repentis-wheat interaction. Phytopathology 89: 444-449.

Tan spot of wheat, caused by the fungus Pyrenophora tritici-repentis, is a destructive disease found in wheat-growing regions worldwide that can lead to serious yield losses. Changes in cultural practices have led to an increase in the severity and incidence of tan spot. Following infection, compatible races of the fungus elicit two distinct symptoms in differential wheat lines: tan necrosis and (extensive) chlorosis. Tan necrosis

and appears to involve at least two other toxins, Ptr ToxB and Ptr ToxC, produced by different races of the fungus. Distinct genes apparently condition the reaction of wheat lines to each of these chlorosis-inducing toxins. This review concentrates on significant advances that have occurred during the past decade in the characterization of this disease interaction, ranging from the epidemiology and management of tan spot to molecular hostparasite interactions. Particular emphasis is placed on work describing fungal race differentiation, production of toxins and their importance in pathogenicity, and the genetics and physiology of host response to infection.
\end{abstract} has been clearly demonstrated by several groups to result from the action of a protein toxin, Ptr ToxA. Wheat sensitivity to this toxin is conditioned by a single dominant gene. The chlorosis response may be more complex
Additional keywords: chlorosis toxin, fungal toxin, host-pathogen interactions, host-selective toxin, necrosis toxin.
Pyrenophora tritici-repentis (Died.) Drechs. (synonym $P$. trichostoma (Fr.) Fuckel), anamorph Drechslera tritici-repentis (Died.) Shoemaker (synonym Helminthosporium tritici-repentis Died.), is a homothallic ascomycete that is responsible for the foliar disease tan spot (synonym yellow leaf spot) of wheat (Triticum aestivum L.) and durum wheat (T. turgidum L. var. durum) $(45,51,74)$. Much of the earlier work on the P. tritici-repentis-wheat interaction concentrated on epidemiological aspects of this disease. An increase in the economical significance and distribution of tan spot has recently fostered an increased awareness and interest among researchers. As such, the past decade has shown significant advances in understanding the molecular aspects of this host-pathogen interaction including toxin purification and biochemistry, the significance of toxins to disease development, and the genetics of the host response. We attempt here to provide the reader with a history of the system and an overall scope of the research developments.

\section{DISEASE OCCURRENCE AND SEVERITY}

Tan spot of wheat has been identified in major wheat-growing areas throughout the world and is a disease of economic importance. The disease was first detected in the United States in New York in 1940 and in Kansas in 1947 and has increased in incidence and severity to the present $(7,42,78,81,92,104)$. By the late $1970 \mathrm{~s}$, the incidence of tan spot increased in Oklahoma and the southern plains of the United States (47). The disease was identified in Canada in 1939, but the first serious outbreak occurred in 1974 (19, 98). Yield losses attributed to this disease have ranged from 3 to $50 \%$ in the central plains of the United States and Canada $(44,84$, 97). Tan spot was reported as the fastest-spreading disease in the Southern Cone region of South America (50), and serious losses have been reported in Argentina, Brazil, and Paraguay $(2,49)$. It is

Corresponding author: L. M. Ciuffetti; E-mail address: ciuffetl@bcc.orst.edu

Publication no. P-1999-0420-01V

(C) 1999 The American Phytopathological Society a major leaf disease in the northern wheat-growing areas of Australia (69). In 1986, tan spot was seen for the first time in Central Asia and soon after was considered to be one of the main wheat diseases, based on surveys of cereal crops (80). The disease was first reported in Mexico in 1982 (37). Due to the wide-ranging spread of the disease and potential destruction, it is of concern to CIMMYT (International Maize and Wheat Improvement Center, Mexico, D.F., Mexico), as evidenced by a special workshop, "Helminthosporium Blights of Wheat: Spot Blotch and Tan Spot," held at CIMMYT to strengthen research partnerships directed at reducing yield losses and at development of potential strategies for disease control (25).

Increases in disease incidence have been attributed to changes in cultural practices (82) including shifts from conventional tillage to conservation- and zero-tillage practices $(3,22,55,96,104)$, shorter rotations and continuous wheat cultivation $(36,81,86,96)$, and the culture of highly susceptible cultivars $(22,85)$. In addition, the change from stubble burning to its retention is believed to be the cause of the increased incidence in Australia and other areas of the world $(10,60,84,85)$. Interestingly, areas that have reported a decline in leaf and stem rusts due to the release of resistant germ plasm are now experiencing an increase in the predominance of $\tan$ spot $(23,35)$. Foliar fungicides can be effective in the control of the disease, but in some areas, costs are prohibitive $(59,81,99)$.

\section{PATHOGEN DESCRIPTION}

The fungus propagates both asexually by conidia and sexually by ascospores. Conidiophores are erect and simple with a swollen base and give rise to conidia that are subhyaline, cylindrical, typically four- to seven-septate, and multinucleate. The basal cell of the conidium is conically tapered and diagnostic. Pseudothecia are black and can be beaked; asci are typically eightspored. Ascospores are brown, three-septate transversely, multinucleate, and range from oval to globose. The asci contain slight septal constrictions, and median cells may exhibit a longitudinal septation $(27,40,91,105)$. 


\section{DISEASE CYCLE}

The fungus is a diurnal sporulator $(35,72,74)$ and conidia are disseminated by wind $(88,106)$. Pseudothecia of $P$. tritici-repentis develop on infected wheat residue and mature over fall and winter, giving rise to ascospores that are forcibly discharged during wet periods the following spring $(41,74,86)$. Ascospores are generally thought to be the source of primary inoculum $(40,51,81,84,96)$, followed by repeated cycles of conidial production on diseased leaf tissue $(45,83,88,106)$. In contrast, studies by Krupinsky (54) indicate conidia may play a primary role in the initiation of a tan spot epidemic in spring wheat in the northern Great Plains. Further studies indicate that ascospores may serve to disperse $P$. triticirepentis over short distances, while long-distance dispersal by wind may be limited to conidia (88). Tan spot severity has been correlated with the levels of infected wheat residue in the field $(76,86$, 96,104,106). P. tritici-repentis is known to infect other gramineous species present in major wheat-growing areas $(53,74,91)$. As such, overwintering of the pathogen on these grasses may provide additional inoculum for spread of the disease. Moisture $(30,42,44,77$, $79,81,95)$, temperature $(44,70,95)$, light $(48)$, plant age or leaf position $(20,43,81,84,90)$, host genotype $(21,59,60,87,97)$, and virulence of the isolate $(37,52,60,71,84)$ are variables reported to contribute to the amount of inoculum produced and the onset and severity of the disease, either together or separately. An increase in nitrogen fertilizer and the proportion of nitrogen utilized as ammonium was shown to reduce lesion development in tan spot (46). Later studies by Bockus and Davis (9), however, suggest that the apparent reduction of disease from $\mathrm{N}$ fertilizers is due to a delay in leaf senescence and not due to a direct effect on tan spot. The conflicting results of the two studies could be due to different rates and forms of $\mathrm{N}$ used; differences in soil type; differences in the wheat cultivars tested (9); or all of the above. Infected kernels, called red smudge (12), cause kernel discoloration; can affect seedling emergence, seedling vigor, yield, and grain quality; and may provide inoculum for epidemics and dispersal of pathogenic strains to new geographic areas $(8,12,31,32,89,103)$.

\section{SYMPTOM DEVELOPMENT AND PATHOTYPE/RACE DESIGNATIONS}

The fungus penetrates the epidermis directly and grows intercellularly through the leaf mesophyll $(24,66,68)$. Typical disease symptoms were originally described as yellow to tan-brown elliptical necrotic lesions with a brown to black point at the center frequently surrounded by a chlorotic border, often spreading to cover the entire leaf $(40,42)$. The two symptoms (necrosis and chlorosis) were considered to be part of the tan spot syndrome, and a number of rating systems were adopted to describe host reactions to $P$. tritici-repentis. The work of Lamari and Bernier $(60,62)$ demonstrated that specific interactions between certain isolates of the fungus and wheat genotypes resulted in the differential development of tan necrosis and chlorosis (including extensive chlorosis). Recognition of independent symptoms (necrosis and chlorosis) on various wheat genotypes provided the basis of a disease system of classification. To categorize host reactions to $P$. tritici-repentis, Lamari and Bernier (59) suggested a rating system based on lesion type $(37,40)$. Under this system, symptoms range from small brown to black spots (resistant) to symptoms consisting of coalescing chlorotic or tan necrotic areas with or without the brown to black centers (highly susceptible) $(59,60)$. Based on the ability of an isolate to induce necrosis and chlorosis on a set of wheat differentials, Lamari and Bernier (60) further suggested a disease system of classification that placed isolates into four pathotypes. They identified isolates that cause necrosis and chlorosis $\left(\mathrm{nec}^{+} \mathrm{chl}^{+}\right.$, pathotype 1), necrosis only ( $\mathrm{nec}^{+} \mathrm{chl}^{-}$, pathotype 2 ), chlorosis only ( $\mathrm{nec}^{-} \mathrm{chl}^{+}$, pathotype 3), and those causing neither phenotype (nec ${ }^{-} \mathrm{chl}^{-}$, pathotype 4 , avirulent). The majority of $P$. tritici-repentis isolates identified be- long to pathotype $1(60)$. The development of necrosis and chlorosis was found to be dependent upon a combination of the host genotype and the isolate of $P$. tritici-repentis tested. Subsequent to the proposed pathotype system, Lamari et al. (65) reported chlorosis-inducing isolates of $P$. tritici-repentis from Algeria that could be distinguished from the original isolates of pathotype 3 by differential wheat response. The Algerian isolates are considered members of pathotype $3\left(\mathrm{nec}^{-} \mathrm{chl}^{+}\right)$in that they are able to induce chlorosis, but in genotypes previously shown to be resistant to other isolates of pathotype 3 . As such, a race designation system was suggested by Lamari et al. (65) that consisted of five races: races 1 to 4 represent the isolates previously designated pathotypes 1 to 4 , respectively, and race 5 represents isolates with the genotypespecific chlorosis-inducing activity of the Algerian isolates. The pathotype 3 designation $\left(\mathrm{nec}^{-} \mathrm{chl}^{+}\right)$given to the Algerian isolates and, in fact, to other members of pathotype 3 can be misleading. This confusion lies in the fact that these isolates are also capable of inducing necrosis in certain susceptible durum wheat cultivars (such as 'Coulter' and 'Sceptre'). Similarly, isolates of race 3 have also been shown to be capable of inducing necrosis in 'Coulter' $(60,65)$. This differential response of necrosis or chlorosis could possibly be attributed to different manifestations of the same recognition event in the different host genotypes. Additional studies are necessary to further resolve these apparent discrepancies.

\section{TOXIN IDENTIFICATION AND PURIFICATION}

The involvement of a toxin(s) in pathogenesis was suggested by both the symptomology of tan spot (40) and the method of fungal colonization of the host $(60,66,68)$. Tomás and Bockus $(100)$ provided the initial evidence that a cultivar-specific toxic compound produced by $P$. tritici-repentis was involved in the development of tan spot of wheat. Further studies by Lamari et al. (61) supported this view. The involvement of a host-specific toxin (HST) in tan spot of wheat was supported by the following. (i) All wheat cultivars or near-isogenic lines that developed typical tan spot necrosis upon inoculation with the fungus were also sensitive to the toxin $(61,100)$. (ii) Resistant lines of wheat were insensitive to the toxin $(61,100)$. (iii) All P. tritici-repentis isolates that caused tan spot symptoms also produced toxin in vitro $(61,100)$. (iv) All isolates lacking the ability to cause tan spot necrosis did not produce toxin in vitro (61). (v) Development of necrotic symptoms, sensitivity to the toxin, and disease susceptibility all appear to be controlled by the same dominant gene (61).

\section{Necrosis-inducing toxin(s)}

The major necrosis-inducing toxin from culture filtrates of $P$. tritici-repentis was initially purified by two groups $(4,101)$ and later by two other groups $(102,107)$ employing slightly different procedures. Although each report described a polypeptide of approximately the same molecular weight, amino acid composition, and sensitivity to chemical reduction, discrepancies regarding the heat stability and specific activity of the toxin exist. Ballance et al. (4) reported that the toxin was a 13.9-kDa protein (designated Ptr necrosis toxin) with an average minimum active concentration of $0.2 \mathrm{nM}$. Tomas et al. (101) described the toxin as a $14.7-\mathrm{kDa}$ protein (designated Ptr toxin) with an average minimum active concentration of $90 \mathrm{nM}$. Tuori et al. (102) described the toxin as a 13.2-kDa protein (designated ToxA) with an average minimum active concentration of $60 \mathrm{nM}$. The lower specific activity reported by Ballance et al. (4) could be attributed to differences in fungal isolates or wheat cultivars used as compared with Tomas et al. (101) and Tuori et al. (102). Differences in molecular weight and heat stability can be attributed to the different methods of characterization; e.g., electrophoretic mobility $(4,101)$ versus the more accurate, mass spectroscopy (102). Although these apparent differences led researchers to speculate that different toxins were described, it now seems more likely that all groups described the same toxin 
(described below). Zhang et al. (107), working with the same isolate (86-124) as Ballance and coworkers (4), reported the primary amino acid sequence of the toxin with the exception of the extreme $\mathrm{N}$-terminus and determined both experimentally, by circular dichroism spectroscopy, and theoretically, by computer-aided secondary structure predictions, that the protein's secondary structure is comprised mostly of $\beta$-sheets.

The necrosis-inducing HST is produced by the fungus both in culture $(4,101,102,107)$ and in planta $(58)$. The 13.2-kDa ToxA protein was shown to be causal to tan necrosis by bioassays of the products of indirect immunoprecipitations (102) and of the protein eluted from polyacrylamide gels $(101,102)$. In addition, incubation of the toxin with antisera raised against the protein eliminated toxic activity (58).

Other necrosis-inducing toxic components from culture filtrates of the fungus also have been described. Tuori et al. (102) isolated anionic (AI) and cationic (CI) protein fractions that elicited cultivarspecific necrosis. Both toxic components were essentially free of ToxA, as determined by native gel electrophoresis and immunological analysis with mouse anti-ToxA antisera. Similarly, Meinhardt and Zhang (73) isolated a protein fraction distinct from Ptr necrosis toxin that induced necrosis; however, this fraction reacted with antisera raised against Ptr necrosis toxin and was thus described as being a possible folding precursor of the toxin. The relation of the major necrosis-inducing toxin (Ptr toxin, Ptr-necrosis toxin, and ToxA) to the other necrosis-inducing toxic components (AI and $\mathrm{CI}$ ) observed in culture filtrates of certain isolates of $P$. tritici-repentis (102) is currently unknown. A possibility that has not yet been ruled out is that the same gene could condition multiple toxins. Potential alternate processing of the necrosis-inducing toxin could result in proteins that are distinct, both chemically and immunologically, yet retain an affinity for the same receptor and, therefore, elicit the same necrotic response. We are currently investigating whether the ToxA protein undergoes alternate proteolytic cleavage that would yield chemically differentiable yet biologically active peptides (R. P. Tuori and L. M. Ciuffetti, unpublished data).

\section{Chlorosis-inducing toxin(s)}

Isolates of races 1 and 3 have been reported to induce extensive chlorosis in particular wheat lines $(60,62)$. A constituent from cell-free culture filtrates capable of inducing similar chlorosis has recently been identified from race 1 isolates and efforts are underway to purify this putative HST (S. W. Meinhardt, personal communication). Additionally, a distinct chlorosis-inducing toxin that is also cultivar specific was identified and partially characterized from culture filtrates of race 5 isolates and was initially described as being between 3.5 and $10 \mathrm{kDa}$ and heat labile (75). Subsequently, an approximately 5-kDa protein, designated Ptr chlorosis toxin, was partially purified (94)

Another low-molecular-weight, chlorosis-inducing compound (also called Ptr toxin) from cultures of $P$. tritici-repentis has been reported (11). Based on its predicted molecular weight of between 800 and 1,800 Da and its lack of host specificity (it affects barley), it was presumed to be a different molecule than the Ptr chlorosis toxin reported by Orolaza et al. (75). Two other groups have reported on phytotoxic components isolated from $P$. tritici-repentis $(1,38)$. It is apparent that isolates of $P$. tritici-repentis are capable of producing multiple toxins, and different isolates of the fungus likely make different combinations of toxins.

\section{CLONING AND CHARACTERIZATION OF THE NECROSIS-INDUCING TOXIN GENE}

Purification of the proteinaceous necrosis-inducing toxin(s) from P. tritici-repentis led to the isolation of a gene responsible for toxin production. Two groups independently cloned a cDNA for the major necrosis-inducing toxin. Ciuffetti et al. $(15,17,18)$ re- ported the molecular cloning of a 917-base pair (bp) cDNA identified from an expression library with antibody to purified ToxA. The identity of this cDNA (designated ToxA) was confirmed by comparison of the predicted open reading frame to amino acid sequence determined from the purified toxin. Ballance et al. $(5,6)$ independently reported the cloning and analyses of a 900-bp cDNA (designated PtrNEC) encoding the Ptr necrosis toxin. Interestingly, the sequences of the two cDNAs differ in only a single base that does not change the coding sequence, although the genes were obtained from geographically separated isolates. Indirect immunoprecipitations of in vitro translation products indicated that the toxin transcript is relatively abundant and the protein is initially synthesized as an approximately $20-\mathrm{kDa}$ precursor. Sequence analysis of the cDNA clones indicated that ToxA encodes a $19.7-\mathrm{kDa}$ preproprotein. The precursor is composed of a signal peptide necessary for secretion, followed by a small domain at the N-terminus comprising an anionic peptide not present in the mature toxin, and finally a larger domain at the $\mathrm{C}$-terminus comprising the mature, cationic toxin (17). Originally, two potential proteolytic cleavage sites were proposed; between Arg-60 and Gln-61 or between Gln-61 and Gly-62 (17). However, we now favor the proteolytic cleavage site following Arg-60 yielding a pyroglutamate residue as the $\mathrm{N}$ terminus of the mature toxin (18). The C-terminal domain very likely does not undergo any significant posttranslational modifications, other than the cyclization of the N-terminal glutamine residue to form a pyroglutamate residue (R. P. Tuori and L. M. Ciuffetti, unpublished data). A genomic clone of the ToxA gene was isolated along with its endogenous promoter, and expression was shown to be sufficient for pathogenicity $(16,17)$. When transformed into a non-toxin-producing, nonpathogenic isolate of the fungus, the gene conferred upon this isolate toxin-producing ability and pathogenicity $(16,17)$. To date, no striking similarity to other genes or proteins has been detected in database searches.

In isolates analyzed thus far, both the ToxA gene and the PtrNEC gene appear to be a single copy gene. The gene is apparently absent from non-toxin-producing (those that do not induce races 1 - and 2-type necrosis) isolates of $P$. tritici-repentis as demonstrated by polymerase chain reaction and Southern blot analyses $(5,16,17)$. Additionally, the PtrNEC gene was shown to be absent from isolates of races 3 and 5 , both considered pathotype 3 (5). We have separated the chromosomes in selected Tox $\mathrm{A}^{+}$and Tox $\mathrm{A}^{-}$ isolates of $P$. tritici-repentis by pulsed-field gel electrophoresis. Our results indicate that the ToxA gene appears to be localized to a single chromosome in all Tox $\mathrm{A}^{+}$isolates tested thus far. Additionally, chromosomal polymorphisms exist among the Tox $\mathrm{A}^{+}$isolates and between $\operatorname{ToxA}^{+}$and ToxA ${ }^{-}$isolates (A. Lichter and L. M. Ciuffetti, unpublished data).

\section{STANDARDIZATION OF TOXIN NOMENCLATURE}

Researchers working on the $P$. tritici-repentis-wheat interaction have proposed a nomenclature for the HSTs and the genes responsible for their production (14). The need for standardization arose from the fact that there are multiple names in the literature for the same toxin (i.e., Ptr necrosis toxin, Ptr toxin, and ToxA) and gene (i.e., ToxA and PtrNEC), and, apparently, multiple toxins produced by $P$. tritici-repentis. The following designations were adopted: (i) Ptr $\operatorname{Tox} A=P t r$ necrosis toxin, Ptr toxin, and ToxA; (ii) Ptr ToxB = Ptr chlorosis toxin from race 5; and (iii) $\mathrm{Ptr}$ ToxC $=$ Ptr chlorosis toxin from race 1 (and potentially from race 3 ), etc. The genes will be named in accordance with their respective toxins, and as such, ToxA = ToxA and PtrNEC. The gene (locus) for Ptr ToxB, when identified, would be $T o x B$, etc. (14).

\section{GENETICS OF RESISTANCE TO TAN SPOT}

The most economical and environmentally safe method for the control of tan spot is durable genetic resistance. Identification of 
the number of loci conditioning resistance and their dominance relationships and linkages is the first step in developing a successful breeding strategy. Determination of resistance and susceptibility relationships of wheat to isolates of $P$. tritici-repentis is not a simple task, given that there are apparently several HSTs produced by this fungus. The genetics of sensitivity to the toxins produced by $P$. tritici-repentis is apparently conditioned by different loci that express either dominant or recessive alleles $(62,64,67)$. Genetic data for sensitivity to Ptr ToxA (synonyms Ptr necrosis toxin, Ptr toxin, and ToxA) clearly indicates a role in pathogenicity (17). Segregation analysis of progeny from crosses between cultivars resistant and susceptible to tan necrosis (and sensitivity to Ptr ToxA) indicates that a single dominant gene confers sensitivity to the toxin and susceptibility to toxin-producing isolates of the fungus $(61,62$, 97). The single recessive gene, designated $t s n 1$, conferring insensitivity to Ptr ToxA and resistance to necrosis-inducing isolates of the fungus was mapped to the long arm of wheat chromosome $5 \mathrm{~B}$ $(28,93)$. Resistance to infection by some isolates of $P$. tritici-repentis has also been described as polygenic $(13,26,67)$; however, it is not known what toxins, if any, were produced by the isolates tested.

Distinct genes appear to condition the reaction of wheat lines to chlorosis-inducing isolates of races 1 and 3 (62) and to chlorosisinducing isolates of race 5 (75). Lamari and Bernier (62) reported that resistance to races 1 and 3 is attributed to a single dominant gene with incomplete dominance observed with some crosses, suggesting the possibility of minor gene(s) action. In contrast, susceptibility to race 5 and sensitivity to Ptr ToxB (synonym Ptr chlorosis toxin) (94) were suggested to be conditioned by a single dominant gene (75). Recently, Faris et al. (29), using conidial inoculations, reported quantitatively controlled resistance to races 1 and 3. A quantitative trait locus (QTL) was identified and demonstrated to be responsible for $35 \%$ of the chlorosis-inducing variation, with four minor QTL contributing to the variation seen in the recombinant population tested. The major QTL was mapped to the short arm of chromosome 1A (29).

\section{RECEPTOR AND SITE- AND MODE-OF-ACTION STUDIES}

As stated above, genetic analyses indicate that sensitivity of wheat to Ptr ToxA and susceptibility to the fungus is dominant and controlled by a single gene. These results suggest that a single gene product directs the differential response of wheat to this toxin. Data explaining the physiological and molecular toxicity of Ptr ToxA in planta is lacking. However, there are a number of laboratories actively working on the molecular characterization of the site- and mode-of-action of this HST.

One hypothesis is that sensitivity to Ptr ToxA results from a dominant allele encoding a gene product involved in the toxinrecognition process. Purification of Ptr ToxA and cloning of the ToxA gene (synonym PtrNEC) provide the tools to investigate this hypothesis. One approach in progress in our laboratory is the use of the yeast two-hybrid assay $(33,34)$ to identify interactions in vivo between the Ptr ToxA protein and proteins from toxin-sensitive wheat. A clear advantage to this approach is that not only does it have the potential to identify wheat proteins that interact with Ptr ToxA, but facilitates the cloning of the genes that encode these proteins. We have identified and sequenced a number of wheat cDNA clones whose products appear to interact with Ptr ToxA (39). Further analyses of these clones should provide insights into relationships of these putative Ptr ToxA-interacting proteins to one another and possibly to the mode-of-action of this toxin.

Kwon et al. $(56,57)$ demonstrated that Ptr ToxA (synonym Ptr necrosis toxin and Ptr toxin) elicited electrolyte leakage in susceptible wheat genotypes. Their data indicate that inhibitors such as vanadate (an inhibitor of $\mathrm{H}^{+}$-ATPases) reduce the amount of toxin-induced electrolyte leakage. However, this protection decreased with time and did not prevent the development of necrosis (57).
Cycloheximide (inhibitor of protein synthesis) was also shown to protect against toxin-induced electrolyte leakage. Interestingly, cycloheximide prevented necrosis development when the inhibitor was coinfiltrated with the toxin (57). The electrolyte-leakage bioassay was used to investigate the effect of temperature on toxin action. Susceptible wheat seedlings failed to develop necrosis or to leak electrolytes when incubated at $4^{\circ} \mathrm{C}$ prior to infiltration of the toxin. The effect of cold treatment on toxin action was reversible (57). Kwon and coworkers (57) suggest that these results support the requirement of active host metabolism and putative signaling mechanisms for toxin action in sensitive wheat cultivars. Previous studies have also shown that the development of necrosis is temperature sensitive and necrosis fails to develop at temperatures $\geq 30^{\circ} \mathrm{C}(56,63)$.

\section{CONCLUDING REMARKS}

Significant progress has been made in understanding the epidemiology and management of tan spot, with particular emphasis on the effectiveness of fungicides for disease management practices, cultural practices affecting incidence and severity, and the identification of sources of resistance for use in breeding programs. Current efforts to understand the molecular aspects of the $P$. tritici-repentis-wheat interaction could be exploited to identify and develop genetically resistant wheat cultivars. Further advances in the purification of the toxins, cloning of their respective genes, and the identification and characterization of the site- and modeof-action of the toxins involved in this plant-microbe interaction will likely be forthcoming. It is anticipated that continued molecular characterization will be exploited for the control of this wideranging and potentially serious disease.

\section{ACKNOWLEDGMENTS}

Due to space limitations, we regret the exclusion from citation of many earlier research articles. The research conducted in our laboratory was supported by grants from the U.S. Department of Agriculture Cooperative State Research Service, The National Science Foundation, and a U.S. Department of Agriculture National Needs Fellowship to R. P. Tuori.

\section{LITERATURE CITED}

1. Alam, K. B., and Karr, Jr., A. L. 1995. Host specific toxins of Pyrenophora tritici-repentis. Thai J. Agric. Sci. 28:395-403.

2. Annone, J. G. 1998. Tan spot of wheat in Argentina: Importance and disease management strategies. Pages 339-345 in: Helminthosporium Blights of Wheat: Spot Blotch and Tan Spot. E. Duveiller, H. J. Dubin, J. Reeves, and A. McNab, eds. CIMMYT (International Maize and Wheat Improvement Center), Mexico, D.F., Mexico.

3. Bailey, K. L. 1996. Diseases under conservation tillage system. Can. J. Plant Sci. 76:635-639.

4. Ballance, G. M., Lamari, L., and Bernier, C. C. 1989. Purification of a host-selective necrosis toxin from Pyrenophora tritici-repentis. Physiol. Mol. Plant Pathol. 35:203-213.

5. Ballance, G. M., Lamari, L., Kowatsch, R., and Bernier, C. C. 1996. Cloning, expression and occurrence of the gene encoding the Ptr necrosis toxin from Pyrenophora tritici-repentis. Mol. Plant Pathol. On-Line. Publication no. 1996/1209ballance.

6. Ballance, G. M., Lamari, L., Kowatsch, R., and Bernier, C. C. 1998. The Ptr necrosis toxin and necrosis toxin gene from Pyrenophora tritici-repentis. Pages 177-185 in: Molecular Genetic of Host-Specific Toxins in Plant Disease: Proceedings of the Third Tottori International Symposium on Host-Specific Toxins. K. Kohmoto and O. C. Yoder, eds. Kluwer Academic Publishers, Dordrecht, the Netherlands.

7. Barrus, M. F. 1942. Yellow-spot disease of wheat in New York State. Plant Dis. Rep. 26:246.

8. Bergstrom, G. C., and Schilder, A. M. C. 1998. Seed pathology of tan spot. Pages 364-368 in: Helminthosporium Blights of Wheat: Spot Blotch and Tan Spot. E. Duveiller, H. J. Dubin, J. Reeves, and A. McNab, eds. CIMMYT (International Maize and Wheat Improvement Center), Mexico, D.F., Mexico.

9. Bockus, W. W., and Davis, M. A. 1993. Effect of nitrogen fertilizers on severity of tan spot of winter wheat. Plant Dis. 77:508-510. 
10. Brennen, J. P., and Murray, G. M. 1988. Australian wheat diseasesAssessing their economic importance. Agric. Sci. 1:26-35.

11. Brown, D. A., and Hunger, R. M. 1993. Production of a chlorosis-inducing, host-specific, low-molecular weight toxin by isolates of $P y$ renophora tritici-repentis, cause of $\tan$ spot of wheat. J. Phytopathol. 137:221-232.

12. Canadian Grain Commission. 1991. Official Grain Grading Guide. Canadian Grain Commission, Winnipeg, Canada.

13. Cantrell, R. G., Elias, E., and Hosford, Jr., R. M. 1985. The inheritance of resistance to tan spot in durum wheat. Agron. Abstr. 77:50.

14. Ciuffetti, L. M., Francl, L. J., Ballance, G. M., Bockus, W. W., Lamari, L., Meinhardt, S. W., and Rasmussen, J. B. 1999. Standardization of toxin nomenclature in the Pyrenophora tritici-repentis/wheat interaction. Can. J. Plant Pathol. 20:422-425.

15. Ciuffetti, L. M., and Tuori, R. P. 1995. Molecular cloning of the gene for the host-specific, low-molecular weight toxin by isolates of Pyrenophora tritici-repentis. (Abstr.) Fungal Genet. Newsl. 42A:41.

16. Ciuffetti, L. M., and Tuori, R. P. 1996. Analysis of the ToxA gene of Pyrenophora tritici-repentis, causal agent of tan spot of wheat. (Abstr.) Phytopathology 86:S91.

17. Ciuffetti, L. M., Tuori, R. P., and Gaventa, J. M. 1997. A single gene encodes a selective toxin causal to the development of tan spot of wheat. Plant Cell 9:135-144.

18. Ciuffetti, L. M., Tuori, R. P., and Gaventa, J. M. 1998. Cloning and expression of the ToxA gene in Pyrenophora tritici-repentis. Pages 167175 in: Molecular Genetic of Host-Specific Toxins in Plant Disease: Proceedings of the Third Tottori International Symposium on Host-Specific Toxins. K. Kohmoto and O. C. Yoder, eds. Kluwer Academic Publishers, Dordrecht, the Netherlands.

19. Conners, I. L. 1939. Yellow leaf blotch. Can. Plant Dis. Surv. 19:12-14.

20. Cox, D. J., and Hosford, Jr., R. M. 1987. Resistant winter wheats compared at differing growth stages and leaf positions for tan spot severity. Plant Dis. 71:883-886.

21. Diaz de Ackermann, M., Hosford, Jr., R. M., Cox, D. J., and Hammond, J. J. 1988. Resistance in winter wheats to geographically differing isolates of Pyrenophora tritici-repentis and observations on pseudoperithecia. Plant Dis. 72:1028-1031

22. Diaz de Ackermann, M., and Kohli, M. M. 1998. Research on Pyrenophora tritici-repentis tan spot of wheat in Uruguay. Pages 134-141 in: Helminthosporium Blights of Wheat: Spot Blotch and Tan Spot. E. Duveiller, H. J. Dubin, J. Reeves, and A. McNab, eds. CIMMYT (International Maize and Wheat Improvement Center), Mexico, D.F., Mexico.

23. Di Zinno, T., Longree, H., and Maraite, H. 1998. Diversity of Pyrenophora tritici-repentis isolates from warm wheat growing areas: Pathogenicity, toxin production, and RAPD analysis. Pages 302-311 in: Helminthosporium Blights of Wheat: Spot Blotch and Tan Spot. E. Duveiller, H. J. Dubin, J. Reeves, and A. McNab, eds. CIMMYT (International Maize and Wheat Improvement Center), Mexico, D.F., Mexico.

24. Dushnicky, L. G., Ballance, G. M., Sumner, M. J., and MacGregor, A. W. 1996. Penetration and infection of susceptible and resistant wheat cultivars by a necrosis toxin-producing isolate of Pyrenophora triticirepentis. Can. J. Plant Pathol. 18:392-402.

25. Duveiller, E., Dubin, H. J., Reeves, J., and McNab, A., eds. 1998. Helminthosporium Blights of Wheat: Spot Blotch and Tan Spot. CIMMYT (International Maize and Wheat Improvement Center), Mexico, D.F., Mexico.

26. Elias, E., Cantrell, R. G., and Hosford, Jr., R. M. 1989. Heritability of resistance to tan spot in durum wheat and its association with other agronomic traits. Crop Sci. 29:299-304.

27. Ellis, M. B., and Waller, J. M. 1976. Pyrenophora tritici-repentis (conidial state: Drechslera tritici-repentis). Commonw. Mycol. Inst. Descriptions Pathogenic Fungi Bacteria No. 494.

28. Faris, J. D., Anderson, J. A., Francl, L. J., and Jordahl, J. G. 1996. Chromosomal location of a gene conditioning insensitivity in wheat to a necrosis-inducing culture filtrate from Pyrenophora tritici-repentis. Phytopathology 86:459-463.

29. Faris, J. D., Anderson, J. A., Francl, L. J., and Jordahl, J. G. 1997. RFLP mapping of resistance to chlorosis induction by Pyrenophora tritici-repentis in wheat. Theor. Appl. Genet. 94:98-103.

30. Fernandes, J. M. C., Sutton, J. C., and James, T. D. W. 1991. A sensor for monitoring moisture of wheat residues: Application in ascospore maturation of Pyrenophora tritici-repentis. Plant Dis. 75:1101-1105.

31. Fernandez, M. R., Clarke, J. M., DePauw, R. M., and Lefkovitch, L. P. 1997. Emergence and growth of durum wheat derived from red smudgeinfected seed. Crop Sci. 37:510-514.

32. Fernandez, M. R., DePauw, R. M., Clarke, J. M., Zentner, R. P., and McConkey, B. G. 1998. Tan spot in western Canada. Pages 73-79 in: Helminthosporium Blights of Wheat: Spot Blotch and Tan Spot. E. Duveiller, H. J. Dubin, J. Reeves, and A. McNab, eds. CIMMYT (International Maize and Wheat Improvement Center), Mexico, D.F., Mexico.
33. Fields, S., and Song, O. 1989. A novel genetic system to detect proteinprotein interactions. Nature 340:245-246.

34. Fields, S., and Sternglanz, R. 1994. The two-hybrid system: An assay for protein-protein interactions. Trends Genet. 10:286-292.

35. Francl, L. 1998. Components of the tan spot disease cycle. Pages 28-36 in: Helminthosporium Blights of Wheat: Spot Blotch and Tan Spot. E. Duveiller, H. J. Dubin, J. Reeves, and A. McNab, eds. CIMMYT (International Maize and Wheat Improvement Center), Mexico, D.F., Mexico.

36. Freebairn, D. M. 1986. Stubble: The key to success. Queensl. Agric. J. July-August:194-195.

37. Gilchrist, S. L., Fuentes, S. F., and Isla de Bauer, M. L. 1984. Determinacion de fuentes de resistencia contra Helminthosporium tritici-repentis bajo condiciones de campo e invernadero. Agrociencia 56:95-105.

38. Hallock, Y. F., Lu, H. S. M., Clardy, J., and Strobel, G. A. 1993. Triticones, spirocyclic lactams from the fungal plant pathogen Drechslera tritici-repentis. J. Natl. Prod. 56:747-754.

39. Hardison, L., and Ciuffetti, L. M. 1998. Identification of the site of action of Ptr ToxA in wheat. Abstr. 1.2.11 in: Int. Congr. Plant Pathol., 7th. ICPP, Edinburgh, Scotland.

40. Hosford, Jr., R. M. 1971. A form of Pyrenophora trichostoma pathogenic to wheat and other grasses. Phytopathology 61:28-32.

41. Hosford, Jr., R. M. 1972. Propagules of Pyrenophora trichostoma. Phytopathology 62:627-629.

42. Hosford, Jr., R. M. 1982. Tan spot. Pages 1-24 in: Proc. Tan Spot Wheat Related Diseases Workshop. R. M. Hosford, Jr., ed. N.D. Agric. Exp. Stn., Fargo.

43. Hosford, Jr., R. M., Jordahl, J. G., and Hammond, J. J. 1990. Effect of wheat genotype, leaf position, growth stage, fungal isolate, and wet period on tan spot lesions. Plant Dis. 74:385-390.

44. Hosford, Jr., R. M., Larez, C. R., and Hammond, J. J. 1987. Interaction of wet period and temperature on Pyrenophora tritici-repentis infection and development in wheats of differing resistance. Phytopathology 77 : 1021-1027.

45. Hosford, Jr., R. M., and Morrall, R. A. A. 1975. The epidemology of leaf spot disease in a native prairie. I. The progression of disease with time. Can. J. Bot. 53:1040-1050.

46. Huber, D. M., Lee, T. S., Ross, M. A., and Abney, T. S. 1987. Amelioration of tan spot-infected wheat with nitrogen. Plant Dis. 71:49-50.

47. Hunger, R. M., and Brown, D. A. 1987. Colony color, growth, sporulation, fungicide sensitivity, and pathogenicity of Pyrenophora tritici-repentis. Plant Dis. 71:907-910.

48. Khan, T. N. 1971. Effect of light on sporulation in Drechslera triticirepentis. Br. Mycol. Soc. Trans. 56:309-311.

49. Kohli, M. M., and Diaz de Ackermann, M. 1998. Evaluating southern cone wheat germplasm for spot blotch and tan spot. Pages 230-240 in: Helminthosporium Blights of Wheat: Spot Blotch and Tan Spot. E. Duveiller, H. J. Dubin, J. Reeves, and A. McNab, eds. CIMMYT (International Maize and Wheat Improvement Center), Mexico, D.F., Mexico.

50. Kohli, M. M., Mehta, Y. R., and de Ackermann, M. D. 1992. Spread of tan spot in the southern cone region of South America. Pages 86-90 in: Advances in Tan Spot Research. Proc. Int. Tan Spot Workshop, 2nd. L. J. Francl, J. M. Krupinsky, and M. P. McMuller, eds. N.D. Agric. Exp. Stn., Fargo.

51. Krupinsky, J. M. 1982. Observations on the host range of isolates of Pyrenophora trichostoma. Can. J. Plant Pathol. 4:42-46.

52. Krupinsky, J. M. 1987. Pathogenicity on wheat of Pyrenophora triticirepentis isolated from Bromus inermis. Phytopathology 77:760-765.

53. Krupinsky, J. M. 1992. Grass hosts of Pyrenophora tritici-repentis. Plant Dis. 76:92-95.

54. Krupinsky, J. M. 1992. Collection of conidia and ascospores of $P y$ renophora tritici-repentis from wheat straw. Pages 91-95 in: Advances in Tan Spot Research. Proc. Int. Tan Spot Workshop, 2nd. L. J. Francl, J. M. Krupinsky, and M. P. McMuller, eds. N.D. Agric. Exp. Stn., Fargo.

55. Krupinsky, J. M., Halvorson, A. D., and Black, A. L. 1998. Leaf spot diseases of wheat in a conservation tillage study. Pages 322-326 in: Helminthosporium Blights of Wheat: Spot Blotch and Tan Spot. E. Duveiller, H. J. Dubin, J. Reeves, and A. McNab, eds. CIMMYT (International Maize and Wheat Improvement Center), Mexico, D.F., Mexico.

56. Kwon, C. Y., Rasmussen, J. B., Francl, L. J., and Meinhardt, S. W. 1996. A quantitative bioassay for necrosis toxin from Pyrenophora triticirepentis based on electrolyte leakage. Phytopathology 86:1360-1363.

57. Kwon, C. Y., Rasmussen, J. B., and Meinhardt, S. W. 1998. Activity of Ptr ToxA from Pyrenophora tritici-repentis requires host metabolism. Physiol. Mol. Plant Pathol. 52:201-212.

58. Lamari, L., Ballance, G. M., Orolaza, N. P., and Kowatsch, R. 1995. In planta production and antibody neutralization of the Ptr necrosis toxin from Pyrenophora tritici-repentis. Phytopathology 85:333-338.

59. Lamari, L., and Bernier, C. C. 1989. Evaluation of wheat lines and cultivars to tan spot (Pyrenophora tritici-repentis) based on lesion type. 
Can. J. Plant Pathol. 11:49-56.

60. Lamari, L., and Bernier, C. C. 1989. Virulence of isolates of Pyrenophora tritici-repentis on 11 wheat cultivars and cytology of the differential host reactions. Can. J. Plant Pathol. 11:284-290.

61. Lamari, L., and Bernier, C. C. 1989. Toxin of Pyrenophora tritici-repentis: Host-specificity, significance in disease, and inheritance of host reaction. Phytopathology 79:740-744.

62. Lamari, L., and Bernier, C. C. 1991. Genetics of tan necrosis and extensive chlorosis in tan spot of wheat caused by Pyrenophora tritici-repentis. Phytopathology 81:1092-1095.

63. Lamari, L., and Bernier, C. C. 1994. Temperature-induced resistance to tan spot [Pyrenophora tritici-repentis] of wheat. Can. J. Plant Pathol. $16: 279-286$

64. Lamari, L., Bernier, C. C., and Smith, R. B. 1991. Wheat genotypes that develop both tan necrosis and extensive chlorosis in response to isolates of Pyrenophora tritici-repentis. Plant Dis. 75:121-122.

65. Lamari, L., Sayoud, R., Boulif, M., and Bernier, C. C. 1995. Identification of a new race of Pyrenophora tritici-repentis: Implications for the current pathotype classification system. Can. J. Plant Pathol. 17:312-318.

66. Larez, C. R., Hosford, Jr., R. M., and Freeman, T. P. 1986. Infection of wheat and oats by Pyrenophora tritici-repentis and initial characterization of resistance. Phytopathology 76:931-938.

67. Lee, T. S., and Gough, F. J. 1984. Inheritance of Septoria leaf blotch ( $S$. tritici) and Pyrenophora tan spot (P. tritici-repentis) resistance in Triticum aestivum cv. Carifen 12. Plant Dis. 68:848-851.

68. Loughman, R., and Deverell, B. J. 1986. Infection of resistant and susceptible cultivars of wheat by Pyrenophora tritici-repentis. Plant Pathol. 35:443-450.

69. Loughman, R., Wilson, R. E., Roake, J. E., Platz, G. J., Rees, R. G., and Ellison, E. W. 1998. Crop management and breeding for control of Pyrenophora tritici-repentis causing yellow spot of wheat in Australia. Pages 10-17 in: Helminthosporium Blights of Wheat: Spot Blotch and Tan Spot. E. Duveiller, H. J. Dubin, J. Reeves, and A. McNab, eds. CIMMYT (International Maize and Wheat Improvement Center), Mexico, D.F., Mexico.

70. Luz, W. C. da, and Bergstrom, G. C. 1986. Effect of temperature on tan spot development in spring wheat cultivars differing in resistance. Can. J. Plant Pathol. 8:451-454

71. Luz, W. C. da, and Hosford, Jr., R. M. 1980. Twelve Pyrenophora trichostoma races for virulence to wheat in the Central Plains of North America. Phytopathology 70:1193-1196.

72. Maraite, H., Berny, J. F., and Goffin, A. 1992. Epidemiology of tan spot in Belgium. Pages 73-79 in: Advances in Tan Spot Research. Proc. Int. Tan Spot Workshop, 2nd. L. J. Francl, J. M. Krupinsky, and M. P. McMullen, eds., N.D. Agric. Exp. Stn., Fargo.

73. Meinhardt, S. W., and Zhang, H. F. 1998. Characterization of the Pyrenophora tritici-repentis necrosis toxin and a folding precursor. Page 31 in: Helminthosporium Blights of Wheat: Spot Blotch and Tan Spot. E. Duveiller, H. J. Dubin, J. Reeves, and A. McNab, eds. CIMMYT (International Maize and Wheat Improvement Center), Mexico, D.F., Mexico.

74. Morrall, R. A. A., and Howard, R. G. 1975. The epidemology of leaf spot disease in a native prairie. II. Airborne spore populations of $P y$ renophora tritici-repentis. Can. J. Bot. 53:2345-2353.

75. Orolaza, N. P., Lamari, L., and Ballance, G. M. 1995. Evidence of a host-specific chlorosis toxin from Pyrenophora tritici-repentis, the causal agent of tan spot of wheat. Phytopathology 85:1282-1287.

76. Pfender, W. F., King, L. G., and Rabe, J. R. 1991. Use of dual-stain fluorescence microscopy to observe antagonism of Pyrenophora triticirepentis by Limonomyces roseipellis in wheat straw. Phytopathology 81:109-112.

77. Pfender, W. F., Pacey, C. A., and Zhang, W. 1988. Saprophytic growth and pseudothecia production by Pyrenophora tritici-repentis in plant tissues held at controlled water potentials. Phytopathology 78:1205-1210.

78. Pfender, W. F., and Wootke, S. L. 1987. Production of pseudothecia and ascospores by Pyrenophora tritici-repentis in response to macronutrient concentrations. Phytopathology 77:1213-1216.

79. Platt, H. W., and Morrall, R. A. A. 1980. Effects of wind speed and humidity on conidium liberation of Pyrenophora tritici-repentis. Can. J. Plant Pathol. 2:58-64.

80. Postnifova, E. N., and Khasanov, B. A. 1998. Tan spot in Central Asia. Pages 107-113 in: Helminthosporium Blights of Wheat: Spot Blotch and Tan Spot. E. Duveiller, H. J. Dubin, J. Reeves, and A. McNab, eds. CIMMYT (International Maize and Wheat Improvement Center), Mexico, D.F., Mexico.

81. Raymond, P. J., Bockus, W. W., and Norman, B. L. 1985. Tan spot of winter wheat: Procedures to determine host response. Phytopathology 75:686-690.

82. Rees, R. G. 1982. Yellow spot, an important problem in the north-eastern wheat areas of Australia. Pages 68-70 in: Proc. Tan Spot Wheat Related Diseases Workshop. R. M. Hosford, Jr., ed. N.D. Agric. Exp. Stn., Fargo.

83. Rees, R. G., and Platz, G. J. 1980. The epidemology of yellow leaf spot of wheat in Southern Queensland. Aust. J. Agric. Res. 31:259-267.

84. Rees, R. G., and Platz, G. J. 1983. Effect of yellow spot on wheat: Comparison of epidemics at different stages of crop development. Aust. J. Agric. Res. 34:39-46.

85. Rees, R. G., and Platz, G. J. 1992. Tan spot and its control-Some Australian experiences. Pages 1-9 in: Advances in Tan Spot Research. Proc. Int. Tan Spot Workshop, 2nd. L. J. Francl, J. M. Krupinsky, and M. P. McMullen, eds. N.D. Agric. Exp. Stn., Fargo.

86. Rees, R. G., Platz, G. J., and Mayer, R. J. 1982. Yield losses in wheat from yellow spot: Comparison of estimates derived from single tillers and plots. Aust. J. Agric. Res. 33:899-908.

87. Riede, C. R., Francl, L. J., Anderson, J. A., Jordahl, J. G., and Meinhardt, S. W. 1996. Additional sources of resistance to tan spot of wheat. Crop Sci. 36:771-777.

88. Schilder, A. M. C., and Bergstrom, G. C. 1992. The dispersal of conidia and ascospores of Pyrenophora tritici-repentis. Pages 96-99 in: Advances in Tan Spot Research. Proc. Int. Tan Spot Workshop, 2nd. L. J. Francl, J. M. Krupinsky, and M. P. McMullen, eds. N.D. Agric. Exp. Stn., Fargo.

89. Schilder, A. M. C., and Bergstrom, G. C. 1995. Seed transmission of Pyrenophora tritici-repentis, causal fungus of tan spot of wheat. Eur. J. Plant Pathol. 101:81-91.

90. Shabeer, A., and Bockus, W. W. 1988. Tan spot effects on yield and yield components relative to growth stage in winter wheat. Plant Dis. 72:599-602.

91. Shoemaker, R. A. 1962. Drechslera Ito. Can. J. Bot. 40:809-836.

92. Sim, T., and Willis, W. G. 1982. Kansas Wheat Disease Losses. Kansas State University, Manhattan.

93. Stock, W. S., Brûlé-Babel, A. L., and Penner, G. A. 1996. A gene for resistance to a necrosis-inducing isolate of Pyrenophora tritici-repentis located on 5BL of Triticum aestivum cv. Chinese Spring. Genome 39: 598-604.

94. Strelkov, S., Lamari, L., Ballance, G. M., and Orolaza, N. P. 1998. Isolation and mode of action of Ptr chlorosis toxin from Pyrenophora tritici-repentis. Pages 137-138 in: Molecular Genetic of Host-Specific Toxins in Plant Disease: Proceedings of the Third Tottori International Symposium on Host-Specific Toxins. K. Kohmoto and O. C. Yoder, eds. Kluwer Academic Publishers, Dordrecht, the Netherlands.

95. Summerell, B. A., and Burgess, L. W. 1988. Factors influencing production of pseudothecia by Pyrenophora tritici-repentis. Trans. Br. Mycol. Soc. 90:557-562.

96. Sutton, J. C., and Vyn, T. J. 1990. Crop sequences and tillage practices in relation to diseases of winter wheat in Ontario. Can. J. Plant Pathol. 12:358-368.

97. Sykes, E. E., and Bernier, C. C. 1991. Qualitative inheritance of tan spot resistance in hexaploid, tetraploid, and diploid wheat. Can. J. Plant Pathol. 13:38-44.

98. Tekauz, A. 1976. Distribution, severity and relative importance of leaf spot diseases of wheat in western Canada in 1974. Can. Plant Dis. Surv. 56:36-40.

99. Tekauz, A., Samborski, D. J., Rourke, D. S. R., and Iverson, A. T. 1983. Diseases of winter wheat in Manitoba in 1983. Pages 63-68 in: Annu. Conf. Manit. Agron. Winnipeg. Manitoba Agriculture, Winnipeg, Canada.

100. Tomás, A., and Bockus, W. W. 1987. Cultivar-specific toxicity of culture filtrates of Pyrenophora tritici-repentis. Phytopathology 77:1337-1340.

101. Tomas, A., Feng, G. H., Reeck, G. R., Bockus, W. W., and Leach, J. E. 1990. Purification of a cultivar-specific toxin from Pyrenophora triticirepentis, causal agent of tan spot of wheat. Mol. Plant-Microbe Interact. 3:221-224.

102. Tuori, R. P., Wolpert, T. J., and Ciuffetti, L. M. 1995. Purification and immunological characterization of toxic components from cultures of Pyrenophora tritici-repentis. Mol. Plant-Microbe Interact. 8:41-48.

103. Vanderpool, T. C. 1963. Pink and smudge-pink discoloration of wheat seed associated with the yellow leaf disease (Drechslera tritici-repentis). Proc. Can. Phytopathol. Soc. 30:19-20.

104. Watkins, J. E., Odvody, G. N., Boosalis, M. G., and Partridge, J. E. 1978. An epidemic of tan spot of wheat in Nebraska. Plant Dis. Rep. 62:132-134.

105. Weise, M. V. 1987. Compendium of Wheat Diseases. 2nd ed. The American Phytopathological Society, St. Paul, MN.

106. Wright, K. H., and Sutton, J. C. 1990. Inoculation of Pyrenophora tritici-repentis in relation to epidemics of tan spot of winter wheat in Ontario. Can. J. Plant Pathol. 12:149-157.

107. Zhang, H.-F., Francl, L. J., Jordahl, J. G., and Meinhardt, S. W. 1997. Structural and physical properties of a necrosis-inducing toxin from $P y$ renophora tritici-repentis. Phytopathology 87:154-160 